This item is the archived peer-reviewed author-version of:

Legal malpractice in Belgium: redress from a client perspective

\title{
Reference:
}

Rutten Stefan, Hubeau Bernard, van Houtte Jean.- Legal malpractice in Belgium: redress from a client perspective

International journal of the legal profession - ISSN 0969-5958 - 24:2(2017), p. 145-157

Full text (Publisher's DOI): https://doi.org/10.1080/09695958.2017.1291431

To cite this reference: http://hdl.handle.net/10067/1401940151162165141 


\section{Legal Malpractice in Belgium: Redress from a Client Perspective}

\section{Introduction}

The functions of Consumer Protection Law encompass, on the one hand, regulating behaviour and correcting misconduct by service providers (a regulatory approach) and, on the other hand, providing redress for consumers when something goes wrong (an end-user approach). However, the second function is somewhat overlooked by both international and national consumer policy and law. ${ }^{1}$ The same can be said with respect to the provision of redress to the consumers of the services of lawyers. Generally, jurisprudence in this regard focuses on a regulatory approach to lawyer discipline, while the end-user perspective of clients lacks such focus. In an attempt to provide greater emphasis on the client perspective, this paper outlines the different forms of redress available in the case of legal malpractice claims in Belgium. ${ }^{2}$ From the client perspective, whether or not a certain duty is expressly embedded in the Code of Ethics of the bar is of little concern; instead, their main concern is which remedies are available to them. The paper thus focuses on the mechanisms that provide direct redress for a client who is a victim of legal malpractice in Belgium.

Firstly, we will discuss some of the limited data available regarding malpractice claims in Belgium. Secondly, we will study in detail the different means of redress available. The most important means of ensuring financial redress is constituted by the collective insurance schemes established by the bar associations. Two different types of insurance scheme can be distinguished. The first compensates clients against errors committed by their attorney (professional liability), while the second compensates clients against the mishandling of their money. Since 1 January 2016, consumers can also approach the Ombudsman Service for Consumer Disputes Involving Attorneys. Finally, any client who cannot obtain redress may take the matter to court.

Disciplinary proceedings under Belgian law cannot provide redress for the consumer either directly or indirectly. Article 477 of the Judicial Code expressly states that it is forbidden to use the outcome of a disciplinary proceeding or elements of it in any criminal, civil or administrative proceedings. This provision of the Judicial Code precludes the client taking any advantage of the

\footnotetext{
${ }^{1}$ http://unctad.org/en/Pages/DITC/CompetitionLaw/ResearchPartnership/Consumer-Redress.aspx.

${ }^{2}$ It is to the merit of H. Kritzer and A. Melville that a workshop regarding this topic was organised at the International Institute for the Sociology of Law in July 2015. This contribution summarises the key findings of the report we presented during this workshop in Oñati.
} 
result of disciplinary proceedings. While the Judicial Code allows the client to initiate a disciplinary inquiry, the client is not considered a party in the further process of disciplinary proceedings.

Belgium is a Federal State, and matters of justice belong to the core competences of this State. As a rule, the Communities or the Regions have no competence in this respect. Notwithstanding that all the legislation regarding attorneys is federal law, the organisation of the bar is regionalised. Both the Flemish Bar Council and the Association of the French- and German-speaking Bars, as well as every local bar, have, within the boundaries of the federal law, the power to issue regulations. Each of the regional associations may issue regulations that legally bind individual attorneys pertaining to the Dutch-speaking and the French- or German-speaking bars respectively. This contribution focuses on the situation with respect to the Dutch-speaking bars, although when it is deemed interesting or necessary, the French- and German-speaking bars will also be discussed.

Finally, the reader should bear in mind that "attorney" and "lawyer" are considered to be synonyms referring to a Belgian legal professional who gives legal advice and represents a client in court when pleading or defending a case. In Belgium, this legal professional carries the title of advocaat (Dutch), avocat (French) or Rechtsanwalt (German).

\section{Legal malpractice in Belgium}

Malpractice refers to negligence or misconduct by a professional, or an instance of negligence or incompetence on the part of a professional, such as a lawyer, a doctor, a dentist or an accountant (Black's Law Dictionary, 2009). Malpractice is improper, illegal or negligent professional behaviour. In Belgium, the data concerning malpractice claims is limited. The most interesting data are published by the Association of French- and German-speaking Bars of Belgium (AFGB), although this study only includes data from the insurer of the primary collective liability insurance concerning the period 2006 to September $2013 .{ }^{3}$

Other interesting data are provided by Depuydt, an attorney specialised in the defence of legal malpractice claims. ${ }^{4}$ At the end of the 1980 s and in 1999 he did two sample studies analysing one hundred cases that he had handled in each period.

\footnotetext{
3 To be consulted online only: http://www.cljb.be/formation/conference-de-midi-les-assurances-collectives-dubarreau/ ETHIAS-25092014.ppt

${ }^{4}$ P. DEPUYDT, “Aansprakelijkheid van de advocaat. Bespreking van enkele grensdomeinen" in H. VANDENBERGHE (ed.) De professionele aansprakelijkheid, Bruges, die keure, 2004, 127-129.
} 


\section{A. Types of errors}

Concerning the types of error, these consecutive studies generally show consistency. Although these figures should be interpreted carefully, they indicate two interesting tendencies. First and foremost, they indicate that more than one in two claims concerns the formal aspects of legal practice. A second trend that becomes apparent is that malpractice claims in recent years may also result from the violation of ethical duties, such as the duty to notify the counsel of an opposing party. ${ }^{5}$

\begin{tabular}{|c|c|c|c|}
\hline Type of error & AFGB 2006-2013 & $\begin{array}{lr}1999 & \text { situation } \\
\text { Brussels } & \text { Bar and } \\
\text { other } & \text { Flemish } \\
\text { Bars (DEPUYDT) }\end{array}$ & $\begin{array}{lr}\text { 1980s } & \text { situation } \\
\text { Brussels } & \text { Bar and } \\
\text { other } & \text { Flemish } \\
\text { Bars (DEPUYDT) }\end{array}$ \\
\hline $\begin{array}{l}\text { Failure to know or ascertain } \\
\text { deadline correctly }\end{array}$ & $39 \%$ & $19 \%$ & $40 \%$ \\
\hline $\begin{array}{l}\text { Procrastination in } \\
\text { performance of services or } \\
\text { lack of follow-up }\end{array}$ & $32 \%$ & $8 \%$ & $8 \%$ \\
\hline Fail to know/apply the law & $12 \%$ & $22 \%$ & $24 \%$ \\
\hline Procedural error & $12 \%$ & $29 \%$ & $15 \%$ \\
\hline $\begin{array}{l}\text { Failure to obtain client } \\
\text { consent }\end{array}$ & $3 \%$ & $9 \%$ & $4 \%$ \\
\hline $\begin{array}{llr}\text { Violation } & \text { of } & \text { the } \\
\text { professional } & \text { code } & \text { of } \\
\text { conduct } & & \end{array}$ & $2 \%$ & $2 \%$ & $0 \%$ \\
\hline Mishandling client moneys & $\mathrm{n} / \mathrm{a}$ & $4 \%$ & $5 \%$ \\
\hline $\begin{array}{l}\text { Liability of attorneys acting } \\
\text { as a court-appointed legal } \\
\text { representative in } \\
\text { commercial matters }\end{array}$ & $\mathrm{n} / \mathrm{a}$ & $7 \%$ & $4 \%$ \\
\hline Total: & $100 \%$ & $100 \%$ & $100 \%$ \\
\hline
\end{tabular}

B. Data on the frequency of legal malpractice claims in different areas of legal practice

\footnotetext{
${ }^{5}$ Art. III.2.1.9-III.2.1.11 of the Code of Ethics of the Flemish Bar Council.
} 
While the AFGB study contains information regarding malpractice in different legal fields, ${ }^{6}$ the other studies mentioned did not. The areas where legal malpractice claims were most common were: personal injury/traffic accidents (18\% of all malpractice claims), property law (16\%), social security and employment (12\%), commercial and company law (11\%), tax (11\%) and family law $(10 \%)$. The claims were less common in other areas of practice, such as construction law $(5 \%)$, criminal law (5\%), procedural law (4\%), liability law (4\%), public law (3\%) and transport law $(1 \%)$.

\section{Limitation clauses and other ways of limiting lability}

Until recently, the personal and unlimited professional liability of a lawyer was justified by and derived from the general ethical duties of "(personal and professional) honour, honesty and integrity". ${ }^{7}$ Personal and unlimited professional liability implied: ${ }^{8}$

- a prohibition on waiving liability in a client-lawyer contract

- a prohibition on placing a ceiling on liability, i.e. limiting liability to a certain amount

- joint liability of the professional partnership/company and the lawyer treating the case (the lawyer who acted for the client was automatically appointed as representative of the legal person). ${ }^{9}$

The opinion that it is inappropriate for members of any liberal profession to exempt themselves from liability has shifted. Currently, it is generally accepted in jurisprudence that a lawyer can exempt him or herself from liability for most negligence. ${ }^{10}$ Any exemption of liability clause in a lawyer-client contract will have to comply with the general requirements and limitations of contract law. Furthermore, when the client is a consumer, the exemption clause must be in accordance with consumer law. Nevertheless, the contractual freedom of a lawyer is more restricted than a mere application of contract law and consumer law. Jurisprudence, referring to

\footnotetext{
${ }^{6}$ J. Ligot and G. David, "La gestion du sinistre" in OBFG (ed.), Les risques du métier. Les risques liés à la responsabilité civile professionnelle des avocats, Brussels, Bruylant-Larcier, 2008, 149.

${ }^{7}$ H. COUSY, "Het 'Noblesse oblige' van het vrij beroep: van aansprakelijkheid tot verzekering", TPR $2004,89$.

${ }^{8} \mathrm{H}$. COUSY, "Nieuwe mogelijkheden tot beperking van de professionele aansprakelijkheid van advocaten en andere beoefenaars van vrije en gereglementeerde beroepen" in C. VAN SCHOUBROECK, Themis 72 - Aansprakelijkheids- en verzekeringsrecht, Bruges, die Keure, 2011, 74, No. 1.

${ }^{9}$ Article 5, litt. a) Regulation of 8 March 1990, enacted by the (former) Belgian Bar Council, concerning the exercise of the legal profession in cooperation: the partner, to whom a case is entrusted, and the company/partnership, are jointly liable towards the client.

${ }^{10}$ H. COUSY, "Nieuwe mogelijkheden tot beperking van de professionele aansprakelijkheid van advocaten en andere beoefenaars van vrije en gereglementeerde beroepen" in C. VAN SCHOUBROECK, Themis 72 - Aansprakelijkheids- en verzekeringsrecht, Bruges, die Keure, 2011, 74-76, No. 2-3.
} 
the Codes of Ethics of the Flemish Bar Council (Article III.1.3.1), only allows attorneys to limit their liability to the available insurance coverage. ${ }^{11}$

Although for some liberal professions the legislator has expressly confirmed that it is possible to exclude the liability of the practitioner when they exercise their profession by means of a professional company or partnership with limited liability, the situation for Belgian attorneys is not expressly regulated. An attorney can exercise their profession in a company. With the exclusion of certain types of commercial companies (such as a public limited company), the attorney can also opt to establish a company with limited liability. ${ }^{12}$ If the attorney exercises their profession in a partnership or company without limited liability, the attorney has unlimited liability for the company's/partnership's debts. This liability includes their personal property.

Until recently, a lawyer who exercised their profession in a company with limited liability was jointly liable with the company. Currently, the exclusion of the liability of the practitioner when exercising their profession by means of a professional company or partnership with limited liability is accepted. The interests of lawyers' clients are maintained by the expansion of the coverage of professional indemnity insurance to all law firms. Hence, the abolishment of joint liability is not detrimental to clients, and proper liability insurance of a law firm with limited liability is assured.

\section{Insurance: an effective means of redress}

\section{A. Professional indemnity insurance}

The Flemish Bar Council and the Association of French- and German-speaking Bars of Belgium provide professional indemnity insurance for all their members. The insurance premium is collected by the local bar and is usually included in the annual membership fee. The insurance coverage of this collective insurance scheme is limited to $€ 1,250,000$ per claim. An excess of $€ 2,500$ must be borne by each lawyer per claim, although this excess only amounts to $€ 1,250$ per claim for trainee lawyers and $€ 300$ when the claim is related to a case where the lawyer provided second-line legal aid upon appointment by the Bureau for Legal Aid (i.e. acted pro bono). ${ }^{13}$ Lawyers and law firms active in areas of law where $€ 1,250,000$ is not sufficient to cover their

\footnotetext{
${ }^{11} \mathrm{Cf}$. the relevant clause in the model "Agreement between a lawyer and a private client", drafted by the Flemish Bar Council.

${ }^{12}$ Law firms are not listed on the roll of the bar association, only natural persons.

13 A. VANDERHAEGEN, “Burgerlijke beroepsaansprakelijkheid”, Ad Rem 2013/1, 15.
} 
professional liability usually conclude excess insurance contracts that provide coverage for higher claims.

As the primary liability insurance is negotiated by and contracted by the Flemish Bar Council or the Association of French- and German-speaking Bars of Belgium, the premium is the same for all bar members. However, trainee lawyers pay a lower contribution/licence fee to the bar for their insurance coverage. Law firms and lawyers often conclude excess insurance policies. Sometimes excess insurance cover is concluded on demand of the client and/or for a specific case. Law firms (acting in the form of a company) and lawyers active in certain domains (corporate law, estate planning, etc.) will often conclude excess insurance contracts.

The collective insurance scheme of the Flemish Bar Council also provides coverage when the lawyer acts as a court-appointed legal representative in civil cases (e.g. the lawyer acts as judicial trustee). No coverage is provided in commercial matters when the lawyer is appointed by the commercial courts (e.g. the lawyer is appointed as a liquidator in insolvency proceedings). ${ }^{14}$ Lawyers acting as court representatives appointed by the commercial courts must arrange supplementary insurance coverage for those activities.

The following risks are expressly excluded: damages caused by activities that are extraneous to the normal activity of an attorney; damages resulting from crime or intended malpractice by the attorney themselves or their co-counsels, trainee lawyers or other personnel; claims resulting from a fee dispute and damages in the case of force majeure. After termination of professional services as a lawyer, the collective insurance scheme of the Flemish Bar Council provides for single coverage up to $€ 1,250,000$ for any subsequent claims. ${ }^{15}$

\section{B. Insurance against insolvency}

The problem of mishandling client moneys held in trust is partly dealt with by way of collective insurance. All damages not compensated by this collective insurance will have to be recovered by the client by way of a malpractice claim and/or by way of filing a complaint as a "civil party"16 in order to start a criminal investigation of and/or prosecution against the attorney.

\footnotetext{
${ }^{14}$ A. VANDERHAEgen, "Burgerlijke beroepsaansprakelijkheid”, Ad Rem 2013/1, 15.

15 A. VAnderhaEgen, "Burgerlijke beroepsaansprakelijkheid”, Ad Rem 2013/1, 15.

${ }^{16}$ In Belgian criminal procedure, a "civil party" is a party in the proceedings that enjoys rights broadly similar to the prosecution and the defence and that acts in order to seek individual monetary compensation.
} 
Both the Flemish Bar Council (FBC) and the Association of French- and German-speaking Bars of Belgium (AFBG) have concluded collective insurance. Both insurance schemes have rather similar conditions. Insurance coverage is only granted when the following conditions are fulfilled:

- The client has to justify and prove the existence of their claim and the fact that their claim should be paid.

- The client has to file a complaint with the chair of the local bar of their attorney.

- The attorney must meet the definition of "insolvency" in the insurance policy. In both policies, this definition is very broad. An attorney is considered "insolvent" when, after formal notice by the chair of their bar, the attorney refuses to refund client moneys or when the attorney does not respond within a month of the formal notice received.

- A disciplinary investigation must have been opened, unless a disciplinary investigation is for some reason legally impossible.

- Non-compliance with the regulations concerning third-party accounts. ${ }^{17}$

The coverage granted in both schemes is limited. In the insurance schemes concluded by the FBC, coverage is limited to $€ 125,000$ per claim per client, with a lifelong limit per member of the bar of $€ 625,000$. Moreover, coverage is limited to a maximum of $€ 2,500,000$ per year. When the annual cap of $€ 2,500,000$ for damages is reached, no coverage is provided for the excess amount. The insurance scheme concluded by the AFBG does not have an annual cap but does include a limitation per claim per client of $€ 50,000$ and a lifelong limit per member of the bar of $€ 250,000$. Logically, no excess is due.

The following risks are expressly excluded: complaints regarding activities that are extraneous to the normal activity of an attorney; personal debts of the attorney towards public authorities (VAT or other taxes, social security, etc.); recovery costs borne by the client; or when the attorney is unable to return the money due to force majeure. Similar to the collective professional indemnity insurance scheme, the collective insolvency scheme does not provide coverage when the lawyer is appointed as a legal representative by the commercial courts (e.g. the lawyer is appointed as a liquidator in insolvency proceedings).

The premium paid by each attorney under the AFGB scheme amounts to $€ 17$ per year. This amount is included in the annual licence fee that the attorney must pay as a member of the bar.

\footnotetext{
${ }^{17}$ Syn. escrow account. Definition in the Code of Ethics: an account at a financial institution that is recognised by the Flemish Bar Council, of which the lawyer is the account holder and in which funds that belong to clients or third parties are received or managed (Article III.2.8.1.2).
} 
As mentioned above, one of the conditions required to benefit from insurance coverage is the opening of a disciplinary proceeding. In principle, this should mean that few cases of mishandled client moneys remain under the radar. From the data of the Flemish Bar Council concerning disciplinary proceedings in the period 2011-2012, the following conclusions can be drawn. ${ }^{18}$ From a population of almost 10,000 attorneys (2011: 9,560 and 2012: 9,863), over a period of two years, 23 infringements regarding mishandling client moneys were prosecuted before the disciplinary board. This means that on an annual basis, 11 to 12 attorneys mishandled their client moneys $(0.12 \%)$. The data available do not report on the number of victims, or on the precise amounts of mishandled client moneys. Presumably, one fraudulent attorney will have several victims before the mishandling is established. Another conclusion is that mishandling client moneys is one of the most common disciplinary infringements prosecuted. The bar was aware of this fact and in 2013 issued a regulation designed to prevent and detect the mishandling earlier. The regulation ${ }^{19}$ introduced a duty for each attorney to report annually to the chair of the bar on every transaction on their third-party accounts. In addition, annually, a number of third-party accounts are randomly selected and thoroughly screened. A final important remark is that mishandling client moneys is severely disciplined. It is reported that often the sanction is disbarment and that mitigating circumstances are not readily taken into account. ${ }^{20}$

\section{Establishment of the Ombudsman Service for Consumer Disputes Involving Attorneys}

According to the new Belgian Code of Economic Law, Book XVI, which implements Directive 2013/11/EU of 21 May 2013 on alternative dispute resolution for consumer disputes ${ }^{21}$ and amends Regulation (EC) No 2006/2004 and Directive 2009/22/EC, every service provider (including those in the liberal professions) must provide for an ADR procedure whenever a contractual dispute arises from a sales or service contract concluded with a consumer. In order to exclude the general competence of the Consumer Ombudsman Service, the Flemish Bar Council decided to create a separate ADR entity:22 the Ombudsman Service for Consumer Disputes Involving Attorneys

\footnotetext{
${ }^{18}$ E. JANSSENS and L. KENIS, Advocatencahier deontologie. Tuchtprocedure en tuchtrechtspraak van de Vlaamse tuchtraden voor advocaten 2007-2012, Brussels, Orde vanVlaamse Balies, 2013, 67.

${ }^{19}$ Currently integrated in the Code of Ethics of the FBC under Section III.2.8.

${ }^{20}$ E. JANSSENS and L. KENIS, Advocatencahier deontologie. Tuchtprocedure en tuchtrechtspraak van de Vlaamse tuchtraden voor advocaten 2007-2012, Brussels, Orde van Vlaamse Balies, 2013, 53.

${ }^{21}$ Defined in the Directive as: a contractual dispute arising from a sales or service contract (Art. 4.1 litt. e) and f)).

${ }^{22}$ Defined in the Directive as: an entity however named or referred to, which is established on a durable basis and offers the resolution of a dispute through an ADR procedure and that is listed in accordance with Article 20(2) of the Directive.
} 
(Ombudsdienst Consumentengeschillen Advocatuur [OCA]). The main motivation for creating a special dispute resolution entity was to safeguard the attorney's legal privilege.

The newly accredited Ombudsman Service organised by the Flemish Bar Council began on 1 January 2016. The Ombudsman Service for Consumer Disputes Involving Attorneys is also known as LIGECA. The head of LIGECA is an attorney/ombudsman. Each local bar must compose a list of at least three members capable of acting as a local ombudsman/mediator. Not all of these local ombudsmen/mediators have been appointed. The attorney/mediator has to be an "accredited mediator", since the continuous training in and existence of a code of conduct for accredited mediators will offer a better guarantee of quality. The general ombudsman's role is to receive all complaints. For each complaint received, the general ombudsman will then appoint a listed attorney of the local bar where the lawyer who the complaint concerns is enrolled. Since the attorney/mediator, in principle, will thus be part of the same local bar association as the attorney concerned in the complaint, doubts of impartiality could arise. Thus, another guarantee of impartiality implemented is the right of the consumer to suspend the procedure when they do not agree with the choice of the attorney/mediator. In such a case, the general ombudsman/mediator will appoint an attorney from another local bar association. The local ombudsman/mediator then attempts to mediate an agreement between the consumer and the attorney. If the mediation is successful, the agreement is binding for all parties. If the attempt of the local ombudsman/mediator fails, the dispute is referred to the general ombudsman, who will then give a non-binding advice suggesting possible solutions. If the parties adopt one of the general ombudsman's proposed solutions, this agreement will be binding. If none of the suggestions of the general ombudsman are accepted, parties can decide whether or not to take the matter to court.

Lodging a complaint is free of charge. The Ombudsman Service disposes of a budget that is sufficient to fulfil its mission. The local bars may decide on fees for the local mediators; however, fees which depend on the result of an out-of-court dispute resolution are not acceptable. Lodging a complaint to be dealt with by the Ombudsman Service cannot be combined with a complaint to the chairman of the bar.

What can we report about the first months (January-July 2016) of the newly accredited Ombudsman Service? To begin with, there were 149 complaints, of which 74 were admitted. ${ }^{23}$ Moreover, the Flemish Bar Council presumes the issues raised in the complaints mainly concern the fees on the one hand and the duration of a lawsuit on the other.

\footnotetext{
${ }^{23}$ Claims were refused when the client had not contacted the lawyer before filing the complaint or when a lawsuit between the client and their lawyer was already pending. Additionally, claims were inadmissible when the client was not a consumer or when the complaint regarded the attorney acting as a court-appointed legal representative.
} 
On the basis of the literature about the criteria of impartial and independent ombudsmen, it can be conclude that these criteria are clearly not met. The criteria, in general terms, are as follows: independence (we do not believe the negotiated conditions to appoint an attorney as an ombudsman/mediator can guarantee full independence); impartiality and fairness (as a consequence, lack of independence can generate a lack of impartiality in the assessment of complaints); credibility of the review process (this still has to be elaborated and put into practice); confidentiality (this issue has not been properly resolved).

\section{Redress through the courts}

If the insurance scheme does not provide coverage or no amicable settlement between attorney and client is reached, the client's last means of redress is filing a claim in court. When the malpractice constitutes a criminal offence (e.g. the embezzlement of client moneys), the consumer has two options. The first is to file a malpractice claim before the civil courts. The second is to file a complaint as a "civil party" 24 in order to start a criminal investigation of and/or prosecution against the attorney. Although we were not able to determine in which cases a client initiated criminal proceedings, we were able to obtain some insight concerning attorneys being prosecuted regarding "profession-related" offences and the criminal and disciplinary outcomes of these prosecutions.

\section{A. Redress through civil proceedings}

In Belgium, the liability of lawyers for professional malpractice results from a breach of contract. There is no absolute immunity from civil liability for lawyers, although the Judicial Code protects lawyers' freedom of speech by protecting them from lawsuits for defamation based on statements they make in court (Articles 444 and 445, Judicial Code). The general provisions of the Civil Code related to service contracts are equally applied to questions of lawyers' liability.

In addition, no specific procedural rules apply in the context of malpractice claims. Worth mentioning is one article of the Code of Ethics for Lawyers of the Flemish Bar Council, which institutes a disciplinary duty for the counsel acting against the lawyer to inform the chairman of the bar when a lawsuit is initiated. Although the duty of notification does not apply to action against a lawyer in their capacity as a court-appointed legal representative, the duty of notification does

\footnotetext{
${ }^{24}$ See definition of "civil party" footnote 16.
} 
apply when their liability is compromised. Since the obligations to notify the chairman and to respect a period of notice are disciplinary rules, no dilatory plea or plea of nullity can be derived from non-compliance with these rules. However, a lawyer who does not give notice of a malpractice claim or does not respect this period of notice can be subject to disciplinary sanction.

\section{B. Redress through criminal proceedings: Criminal offences committed by lawyers and the role of the Prosecutor General's Office in Antwerp}

Before analysing the data we obtained from the Prosecutor General's Office it seems necessary to briefly elaborate on the role of the Office when a criminal offence is committed by a lawyer. In general terms, the procedure may be described as follows:

- Notification of the Prosecutor General by the Public Prosecutor. The role of the Public Prosecutor's Office in cases involving offences by lawyers is essentially "to notify": it is required to inform the Prosecutor General of the fact that a lawyer is the subject of investigative proceedings or a judicial inquiry.

- The Prosecutor General decides whether to proceed with the prosecution.

- Notification of the chairman of the bar regarding the outcome of the criminal procedure (conviction or not). The chairman of the bar is in turn informed by the Prosecutor General as soon as the investigative proceedings or judicial inquiry has been completed. The underlying rationale of this timing is that this will prevent the chairman of the bar being provided with information that may impede the ongoing investigation, primarily because notification of the chairman of the bar usually results in the latter summoning the lawyer in question. Only in very serious and/or media-sensitive cases may the Prosecutor General inform the chairman of the bar during the investigative proceedings and/or judicial inquiry. In other words, the timing of notification depends on the nature of the case.

- The chairman of the bar may commence disciplinary proceedings.

Pursuant to Article 458, par. 1 of the Judicial Code, it is the Chairman of the bar who must instigate disciplinary proceedings. Under no circumstances can the Prosecutor General instigate such proceedings. The Prosecutor General's Office is, however, responsible for the "implementation" of any disciplinary punishment of which it has been notified by the disciplinary board and that: (a) is definitive and (b) consists in suspension or disbarment (no other disciplinary decisions). ${ }^{25}$ For this reason, the only disciplinary decisions that the Prosecutor General is notified of are those in which a lawyer is suspended or disbarred.

\footnotetext{
${ }^{25}$ Article 470 of the Judicial Code: "The Prosecutor General will see to the implementation of decisions to suspend or disbar".
} 
1. Analysis of criminal offences committed by lawyers and reported to the Prosecutor General's Office in Antwerp

Our research focuses on information obtained from the Prosecutor General's Office in Antwerp pertaining to the reference period of 1 September 2010 to 8 November 2013. Hence, in most of these cases, the lawyers concerned belonged to the Antwerp bar.

The 68 cases reported during the reference period can be subdivided into "profession-related" offences and "other" offences. Profession-related offences are defined as "any infraction committed in the capacity of lawyer". ${ }^{26}$ On average, $25 \%(17 / 68)$ of the offences committed by the members of the bar were "profession-related".

\section{Overview of criminal law procedures}

In order to examine if and to what extent criminal proceedings constitute an effective way of redress, here we ascertain how the Public Prosecutor's Office dealt with reported infractions and to what effect. It is interesting in this respect to distinguish between the approach taken by the Public Prosecutor's Office to profession-related infractions, "other" (non-profession-related) infractions, and various clusters of infractions, respectively (by cluster we mean a concentration of one or more profession-related infractions and one or more non-profession-related infractions).

The Public Prosecutor's Office initiated prosecution in 41 cases $(60 \%)$, while in six cases it took no action (9\%) and in 21 instances it made a referral (31\%), adding up to a total of 68 cases reported.

As for the non-profession-related infractions, these are more likely to result in prosecution (37/46; $80.5 \%$ ). Few cases result in referral, for instance to a labour tribunal with a view to prosecution before the Labour Court.

Clusters of infractions invariably result in action being taken. However, the number of referrals $(2 / 5 ; 40 \%)$ is about the same as the number of own actions $(3 / 5 ; 60 \%)$. Possibly in the case of clusters of infractions, sometimes the criminal law aspect weighs more heavily than the disciplinary element and vice versa.

\footnotetext{
${ }^{26}$ With respect to the data obtained from the Prosecutor General's Office, it should be noted that we only received summaries of each dossier. When it was not completely certain that the offence had been committed in the capacity of a lawyer, we classified it as a non-profession-related offence.
} 
As regards the results of the action taken, all (prosecuted) profession-related infractions resulted in a conviction $(1 / 1 ; 100 \%)$, while non-profession-related infractions usually resulted in a conviction $(29 / 37 ; 78 \%)$. In just six instances the case was either settled out of court or through penal mediation $(3 / 37 ; 8 \%$ and $3 / 41 ; 7 \%)$.

\section{Overview of disciplinary follow-up}

The data show that in a majority of cases the chairman of the bar was indeed notified by the Prosecutor General (82\%). In some cases (8\%), another Public Prosecutor's Office was notified, generally with a view to notification of the chairman of the bar. In $10 \%$ of the cases considered, no notification had taken place (yet).

How do bar presidents respond to such notifications? We can distinguish between four possibilities. Firstly, action may be taken, meaning that the chairman of the bar either orders a disciplinary inquiry, imposes disciplinary sanctions or takes an interim measure (e.g. courtroom ban) against the lawyer concerned. Secondly, the chairman of the bar may request further notification or express an intention to launch a disciplinary inquiry or to take other appropriate action. Thirdly, the chairman of the bar may announce that no disciplinary inquiry will take place or that disciplinary measures or mediation are awaited. Fourthly, there may be no communication from the chairman of the bar to the Prosecutor General (other than a statement that they had already been notified) following notification of the former.

In the majority of cases, further communication takes place $(39 / 58 ; 69 \%)$. Nevertheless, in a substantial proportion, this is not the case $(15 / 58 ; 27 \%)$. Usually $(21 / 56 ; 37 \%$ of cases $)$, action is taken. In 13/56 (23\%) of cases, the chairman of the bar expressed an intention to take action. The proportion of cases where the chairman of the bar announced that no further action will be taken was only $7 / 56(12.5 \%)$.

Strikingly, in over $42 \%(18 / 43)$ of the cases, the case was closed after a hearing of the lawyer concerned by the chairman of the bar (in instances where the chairman of the bar took immediate action or had already taken action). In other words, while a hearing often suffices, in most cases $(25 / 43 ; 58 \%)$ further prosecution does take place, sometimes leading to a courtroom ban for the lawyer in question $(9 / 43 ; 21 \%)$. It should also be noted that disciplinary sanctions had been imposed proactively in only $6 \%$ of the cases considered. 


\section{Conclusion}

The current means of redress are a patchwork of very different procedures. Principally, redress is possible through the collective insurance scheme offered by the bar associations. However, these insurance schemes leave some forms of legal malpractice unprotected: malpractice of attorneys acting as a legal representative appointed by the commercial courts ${ }^{27}$ and cases of gross negligence or intentional malpractice are not covered. The liability of attorneys acting as a court-appointed legal representative in commercial matters is mostly dealt with by additional insurance.

In the assumption that in most cases of gross negligence or intentional malpractice criminal prosecution is an option, our research seems to indicate that profession-related offences are usually referred for prosecution and most likely result in a conviction. Whether this conviction also means that the client will be fully compensated remains an open question.

This analysis of the current means of redress has established that at first sight the current patchwork has no major holes. However, future research is necessary to evaluate the effectiveness of the different means of redress. One of the drawbacks of our exploratory study is the lack of data on client satisfaction regarding the different means of redress, or on the availability of information on victims of legal malpractice. In the coming years, it will be interesting to observe the impact of the Ombudsman Service for Consumer Disputes Involving Attorneys.

\footnotetext{
${ }^{27}$ This type of liability amounts to $5 \%$ of all malpractice claims, see P. DEPUYDT, "Aansprakelijkheid van de advocaat. Bespreking van enkele grensdomeinen" in H. VANDENBERGHE (ed.) De professionele aansprakelijkheid, Bruges, die Keure, 2004, 127-129.
} 